\title{
Botulinum Toxin Type A and Its Possible Mechanisms on Wound Healing
}

\author{
Khushboo Gurung1, Qian Tan ${ }^{1,2}$, Ye Xu², Bingchen Duan ${ }^{3}$ \\ ${ }^{1}$ Department of Burns, Plastic and Reconstructive Surgery, Nanjing Drum Tower Hospital, Affiliated to Medical School of \\ Southeast University, Nanjing, China \\ ${ }^{2}$ Department of Burns, Plastic and Reconstructive Surgery, Nanjing Drum Tower Hospital, Affiliated Hospital of Nanjing \\ University, Nanjing, China \\ ${ }^{3}$ Nanjing Drum Tower Hospital, Clinical College of Nanjing Medical University, Nanjing, China \\ Email: *smmutanqian@sina.com
}

How to cite this paper: Gurung, K., Tan, Q., Xu, Y. and Duan, B.C. (2020) Botulinum Toxin Type A and Its Possible Mechanisms on Wound Healing. Modern Plastic Surgery, 10, 38-55. https://doi.org/10.4236/mps.2020.103006

Received: April 2, 2020

Accepted: May 5, 2020

Published: May 8, 2020

Copyright () 2020 by author(s) and Scientific Research Publishing Inc. This work is licensed under the Creative Commons Attribution International License (CC BY 4.0).

http://creativecommons.org/licenses/by/4.0/

(c) (i) Open Access

\begin{abstract}
Botulinum toxin type-A (BTX-A), a subtype from known seven types of botulinum neurotoxin (serotype A-G), is produced by a gram-positive bacterium, Clostridium botulinum. The toxin is now widely and efficiently used in treating a plethora of diverse symptoms and conditions. Recent evidence in the literature also shows that BTX-A exhibits a wide range of effects on non-neuronal cells. Its potential has markedly expanded to clinical applications other than the treatment of neurological and muscular conditions that are characterized by neuronal hyperactivity. A number of studies have shown BTX-A to improve the quality of scar outcome and prevent the formation of keloids and HTS. Although the mechanism of action of BTX-A on wound healing is still not clearly understood, lately there has been extensive research to grasp the underlying mechanisms of this multifunctional toxin. BTX-A seems to affect wound healing by a number of mechanisms that include action on tensile forces, inhibition of fibroblasts differentiation, downregulation of TGF- $\beta 1$ and collagen expression. This review will explore the responses of Botulinum toxin type-A on wound healing and preventing pathological scars like HTS and keloids, and comprehend the overall effect BTX-A has on wound healing.
\end{abstract}

\section{Keywords}

Wound Healing, Botulinum Toxin Type-A, Hypertrophic Scar, Keloid, Fibroblast, Myofibroblasts, Transforming Growth Factor $\beta$-1, Collagen, Metalloproteinases, Connective Tissue Growth Factor

\section{Introduction}

Scars, especially hypertrophic or keloids have been of particular interest in plas- 
tic and reconstructive surgery due to their recurrences and the therapeutic dilemma in treating them successfully. Disfiguring scars can be very distressful to patients regarding their appearance, particularly when located in the noticeable areas like head and neck; and can have an economic burden and psycho-sociological impact on the patients [1] [2]. Wound healing in itself is a very complex process involving various components and synchronous events that interplay as a consequence of chemical signaling between the various cells involved. Slight imbalance in any of these fragile processes can result in extensive fibrosis and give rise to abnormal scarring like HTS and keloids. So, many of the treatment modalities available these days have focused on this principle to control and prevent extensive hyper-proliferation of scar tissues. The benefits of early intervention on the outcome of various types of scars have been documented in the literature, yet no consensus on prevention or optimal treatment regime for scars has been manifested till now [3]. Other than intralesional steroid injection, application of pressure garments, laser and radiation therapy, scar excision, or various other methods, there is a lesser known treatment of injecting botulinum toxin type-A intralesionally that has been successfully reported over the years in the literature. The first complete description of clinical botulism ("sausage poisoning") published by Justinus Kerner was in the year 1820 [4] [5], and since then the application of botulinum toxin has been very wide and versatile. Hagenah et al. used BTX-A as a research tool to study the spinal cord physiology and published reports in 1977 [6]. Perception of botulinum toxin began to slowly change over the years, and in the early 1980s it took a turn when its therapeutic potential was finally realized. Over the years, it has been commonly used in medicine to treat chronic myofascial pain [7], headache [8], hyperhidrosis [9], urinary incontinence [10], various muscle spasms and diseases characterized by overactive muscle, or more recently in cosmetic applications [11] [12]. Several commercial toxins are available in the market under the brand names such as Botox and Dysport, among many others [13] [14].

\subsection{BTX-A: Structure, and Mode of Action}

Botulinum toxin-A released in its inactive form is a complex mixture of single polypeptide chain consisting of botulinum neurotoxin-A with a nontoxic non-hemagglutinin protein $(\mathrm{NTNH})$ and other various associated non-toxic proteins (HA-hemagglutinin protein). When cleaved by its own proteases, it is converted into an active form consisting of a light chain $(\mathrm{L} ; 50-\mathrm{kDa})$, and a heavy chain $(\mathrm{H} ; 100-\mathrm{kDa})$, with 3 domains weakly held together by a peptide belt, a disulfide bond, and surface charges [15] [16]. Botulinum neurotoxin causes flaccid paralysis by binding pre-synaptically to high-affinity receptors on the cholinergic nerve terminals and thus inhibiting the release of acetylcholine from presynaptic neurons at the neuromuscular junction (NMJ) resulting in chemical denervation at the motor end plate [17].

The mechanism of nerve terminal intoxication by the botulinum neurotoxin is divided into five major steps, 1) binding to neuronal cell membrane (dual-receptor 
complex), 2) botulinum neurotoxin-receptor complex internalization within an endocytic compartment, 3) low $\mathrm{pH}$ driven translocation of L chain across the vesicle membrane, 4) Thioredoxin (Trx) catalyzes the reduction of a disulphide bond releasing L-chain into the cytosol, and 5) cleavage of soluble $\mathrm{N}$-ethylmaleimide-sensitive factor attachment protein receptor (SNARE) substrate, and ensuing inhibition of membrane fusion and acetylcholine (ACh) release, thus leading to neuroparalysis as shown in Figure 1 [18] [19]. Proximal axonal sprouting and muscle re-innervation by the formations of new NMJ leads to toxin recovery [20].

\subsection{The H Chain}

The $\mathrm{H}$ chain has two domains, $\mathrm{HN}-\mathrm{a}$ translocation domain, and $\mathrm{HC}-\mathrm{a}$ receptor-binding domain. The HC domain can be further divided into two distinct subdomains: 1) a carboxyl-terminal $\beta$-trefoil (HCC), and 2) an amino-terminal lectin-like jelly roll ( $\mathrm{HCN})$ [21]. The $\mathrm{H}$ chain provides specificity and binds the toxin to presynaptic receptors, and promotes L-chain translocation across the endosomal membrane. The HN domain has a central role in the translocation of the $\mathrm{L}$ chain across the membrane of the endocytic vesicle into the neuronal cytosol [16]. The HCC (binding domain), mediates neuro-specific binding of the toxin to a polysialoganglioside and also binds to a protein receptor, together they form a dual-receptor complex. This results in an accelerated and active interaction of the toxin with peripheral cholinergic nerve endings [22] [23] [24]. Although specific function of lectin-like HCN domain is yet unknown, evidence suggests it may promote attachment of BTX-A to the pre-synaptic membrane by interacting with certain anionic lipids [25].

\subsection{The L Chain}

The $\mathrm{L}$ chain is a metalloproteinase, possessing a zinc endopeptidase from the M27 family of peptidases, and is an active part of the toxin. It enters peripheral cholinergic nerve terminals where it cleaves the synaptosomal-associated protein SNAP-25 (SNARE protein family): a presynaptic membrane protein required for fusion of neurotransmitter containing vesicles [19] [26]. It impedes vesicle-plasma

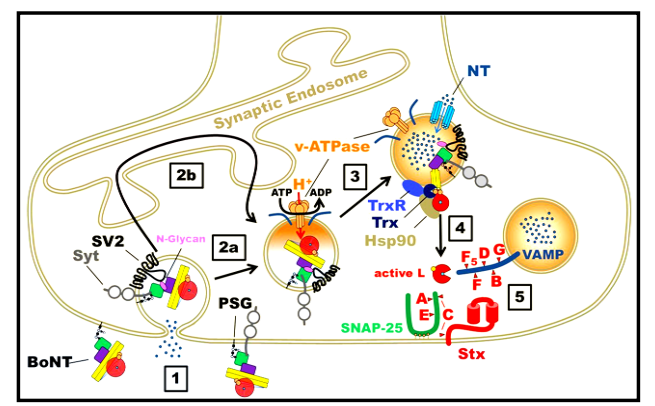

Figure 1. Mechanism of intoxication by various Botulinum neurotoxins, A-G. (PSG, polysialoganglioside; Syt, synaptotagmin; SV, synaptic vesicle; Stx, syntaxin; Trx, thioredoxin; TrxR, thioredoxinreductase; VAMP, vesicle-associated membrane protein). 
membrane fusion resulting in persistent but reversible inhibition of acetylcholine release from axon endings producing flaccid paralysis [17] [27]. The seven toxin types (A-G) have different tertiary structures and sequence differences, and different toxin types target different SNARE family members [28]. This specificity of action has made them effective therapeutic agents for various syndromes caused by overactive cholinergic nerve terminals. The scope of clinical applications of BTXA is rapidly growing and is now being substantially used to treat a broad range of clinical conditions [17].

\section{Wound Healing}

To understand the mechanisms of BTX-A on the outcome of scars, comprehending the process of wound healing is very crucial. When the skin is broken, an intricately regulated process involving multiple overlapping sequences of biochemical events are set into motion to repair the damage. The phases of wound healing are: 1) hemostasis, 2) inflammatory response and cellular migration, 3) proliferation (neo-angiogenesis, formation of granulation tissue and ECM, re-epithelialization), and 4) tissue remodeling. Upon wounding, initial vasoconstriction along with activation of the clotting cascade achieves hemostasis. Platelets that come in contact with the exposed sub-endothelium, tissue factor and collagen lead to further platelet aggregation and degranulation [29]. Platelets release various chemokines, growth factors (GFs like TGF, PDGF, etc.), and other pro-inflammatory mediators, which induce migration of a variety of cells into the wound site [30]. In the inflammatory phase, the actions on cell receptor by these cytokines, chemokines, GFs, proteases, $\mathrm{pH}$ gradients, $\mathrm{pO}_{2}$ gradients modulate intracellular signaling cascade that results in cell proliferation, migration, and differentiation [27].

Activated by various GFs like TGF- $\beta$ family (TGF- $\beta 1, \beta 2$, and $\beta 3$ ), IL family and angiogenesis factors (VEGF), the population of fibroblasts, keratinocytes, endothelial cells, and connective tissue greatly increases in the proliferative phase. Fibroblasts lay down ECM proteins including proteoglycans, fibronectins, and hyaluronic acid at the wound site and produce collagen and fibronectin, and eventually replace the temporary fibrin clot [31]. Thus formed granulation tissue is heavily vascularized by local angiogenesis [31] [32]. Different types of cells that are involved in the process of inflammation, neo-angiogenesis, and connective tissue synthesis adhere to, proliferate and differentiate on the collagen matrix produced and laid down by the fibroblasts. Whereas, myofibroblasts (transformed fibroblasts) connect to the surrounding protein collagen and fibronectin, assisting in wound contraction and promoting angiogenesis through matrix metalloproteinases (MMP) [33]. Remaining epithelial appendages near the wound and epithelial cells from around the wound border continue to repair the epidermis [34]. This phase continues for days and weeks [35].

The final step in wound healing is the remodeling phase and can take up to one or more years [29]. This stage in the wound healing needs a precise balance between the synthesis and degradation of ECM. Fibroblasts regulate both the 
turnover and gradual breakdown of ECM by MMPs, and replacement of immature type III collagen by mature type I collagen [29] [30] [32]. As the scar matures over time, vascularity decreases and scar color changes, but only partially regains its original tensile strength. Although repair of the functional barrier is highly efficient, it does not always operate properly, and any disruption in the aforementioned processes will lead to uncontrolled wound healing resulting in two major pathological states: ulcerative defect or excessive scar formation like a hypertrophic scar or keloid [33] [35].

Hypertrophic scars (HTS) and keloids both are raised, thickened and firm scars formed due to overexpression of collagen during wound healing. Even though both can be pruritic, painful, it is also restricting and disfiguring, and there is a clear distinction between the two [36]. Unlike HTS, keloids are not contained within borders of the original injury, tend to overgrow into large benign tumors, can recur after excision, and are genetically predisposed. Often times HTS is self-limiting and can fade with time. However, studies have suggested hypertrophic scarring to be prevalent in darker skin populations and areas of skin subjected to tension [30] [36].

\section{Effects and Potential Mechanisms of BTX-A on Wound Healing}

\subsection{Direct Inhibition of Active Fibroblasts and Increased Apoptosis}

Over the years, there have been several in vitro as well as in vivo studies that have concluded that BTX-A is not only a neurotoxin but tends to have a molecular effect on a cellular level, particularly the inhibition of fibroblasts. Shown in Table 1 is a summary of studies which have indicated that BTX-A not only directly inhibits the proliferation but also affects the cell cycle distribution of fibroblasts derived from keloid, HTS, and scar contracture tissues when compared with normal fibroblasts [37]-[44]. Zhibo and colleagues conducted several studies to show the effect of BTX-A on fibroblasts derived from HTS and keloids. In one study, fibroblasts treated with BTX-A at the dose of $1 \mathrm{U} / 10^{6}$ cells and 2.5 $\mathrm{U} / 10^{6}$ cells showed $58 \%$ and $61 \%$ in G0 to G1 phase, $8 \%$ and $9 \%$ in G2 to $\mathrm{M}$ phase, and $34 \%$ and $30 \%$ in S phase, respectively, showing a greater population of fibroblast arrested in G0 to G1 phase [40]. BTX-A effectively inhibited the proliferation of fibroblasts derived from HTS and also decreased CTGF protein thereby preventing excess collagen deposition. In another experiment, $64 \%$ of BTX-A treated fibroblast were in G0 to G1 phase compared to only $36 \%$ of control fibroblasts; a greater number of the control fibroblasts were in the proliferative phase ( $21 \%$ G2 to M; $43 \%$ in S) [45]. In yet another study by Zhibo et al., keloids treated with intralesional BTX-A (70 to $140 \mathrm{U}$ ) per session at a 3-month interval for a maximum of 9 months showed striking outcomes. With no therapy failures and very high patient satisfaction $25 \%$ of subjects reported excellent, 41.6\% good, and 33\% fair [43]. Another similar study with 19 patients treated 
Table 1. Effects of botulinum toxin type-A. Summary of studies included.

\begin{tabular}{|c|c|c|c|c|}
\hline $\begin{array}{l}\text { First Author } \\
\text { (year) }\end{array}$ & $\begin{array}{c}\text { Study } \\
\text { type/Details }\end{array}$ & $\begin{array}{l}\text { Type of } \\
\text { Scar/Cell }\end{array}$ & $\begin{array}{c}\text { Toxin } \\
\text { Application }\end{array}$ & Results \\
\hline $\begin{array}{l}\text { Xiao Z et al. } \\
(2009)[44]\end{array}$ & $\begin{array}{l}\text { Prospective } \\
\text { uncontrolled } \\
\text { trial. } 6 \text { months } \\
\text { follow-up }\end{array}$ & $\begin{array}{l}\text { Active HTS } \\
\text { from } \\
19 \text { patients }\end{array}$ & $\begin{array}{l}\text { Intralesional BTX-A } \\
\text { injection of } 2.5 \mathrm{U} \text { per } \\
\text { cubic cm of lesion, once } \\
\text { monthly for } 3 \text { months }\end{array}$ & $\begin{array}{l}\text { All patients showed acceptable improvement and high rate of } \\
\text { therapeutic satisfaction. Scores for erythema, itching sensation, } \\
\text { and pliability post BTX-A injections were significantly lower } \\
\text { than prior to BTX-A injections }(\mathrm{p}<0.01) \text {. }\end{array}$ \\
\hline $\begin{array}{l}\text { Xiao Z et al. } \\
(2011)[40]\end{array}$ & $\begin{array}{l}\text { In-vitro/cell } \\
\text { culture study }\end{array}$ & $\begin{array}{l}\text { HTS derived } \\
\text { FBs from } 8 \\
\text { different } \\
\text { patients }\end{array}$ & $\begin{array}{l}3 \text { groups; cells treated with } \\
\text { BTX-A in concentrations } \\
\text { of } 1 \mathrm{U} / 10^{6} \text { cells vs. } \\
2.5 \mathrm{U} / 10^{6} \text { cells vs. control }\end{array}$ & $\begin{array}{l}\text { Proliferation of FBs treated with BTX-A was slower than of FBs } \\
\text { without BTX-A }(\mathrm{p}<0.01) \text {. Compared with FBs without BTX-A, } \\
\text { BTX-A at } 1 \mathrm{U} / 10^{6} \text { cells decreased expression of CTGF by } 49.2 \% \\
\pm 12.5 \%(\mathrm{p}<0.01) \text {, and BTX-A at } 2.5 \mathrm{U} / 10^{6} \text { cells, decreased } \\
\text { CTGF expression by } 56.9 \%(\mathrm{p}<0.01) \text {. }\end{array}$ \\
\hline $\begin{array}{l}\text { Zhibo X et al. } \\
\quad(2008)[45]\end{array}$ & $\begin{array}{l}\text { In-vitro/cell } \\
\text { culture study }\end{array}$ & $\begin{array}{l}\text { FBs cultured } \\
\text { from HTS of } \\
8 \text { different } \\
\text { patients }\end{array}$ & $\begin{array}{l}\text { FBs in } 1 \mathrm{U} / 10^{6} \mathrm{BTX}-\mathrm{A} \\
\text { vs. control FBs }\end{array}$ & $\begin{array}{l}\text { Significant differences in cell cycle distribution between } \\
\text { experimental ( } 64 \% \text { in G0 - G1, } 6.4 \% \text { in G2-M, } 29 \% \text { in S phase), } \\
\text { compared to control FBs ( } 36 \% \text { in G0 - G1; majority in } \\
\text { proliferative phase; } 21 \% \text { in G2-M, } 43 \% \text { in S), (p }<0.01) \text {. }\end{array}$ \\
\hline $\begin{array}{l}\text { Jeong HS et al. } \\
\text { (2015) [37] }\end{array}$ & $\begin{array}{l}\text { In-vitro/cell } \\
\text { culture study }\end{array}$ & $\begin{array}{l}\text { HTS derived } \\
\text { FBs vs. normal } \\
\text { mature scar } \\
\text { derived FBs }\end{array}$ & $\begin{array}{l}\text { FBs treated with } \\
\text { BTX-A } 4 \mathrm{U} / \mathrm{ml} \text { vs. control }\end{array}$ & $\begin{array}{l}\text { FB proliferation in both normal mature scar and hypertrophic } \\
\text { scar tissue decreased significantly after treatment with } 4 \mathrm{U} / \mathrm{ml} \\
\text { BTX-A }(\mathrm{p}<0.001) . \alpha \text {-smooth muscle actin mRNA and proteins } \\
\text { also decreased in BTX-A treated group compared to control } \\
\text { (TGF- } \beta 1 \text { only) of FBs derived from HTS, but not FBs derived } \\
\text { from normal mature scars. FBs to myofibroblasts } \\
\text { differentiation decreased in FBs of HTS after BTX-A treatment. }\end{array}$ \\
\hline $\begin{array}{l}\text { Xiao Z Qu G. } \\
\text { (2012) [39] }\end{array}$ & $\begin{array}{l}\text { In-vivo } \\
\text { experiment } \\
\text { (animal } \\
\text { model) }\end{array}$ & $\begin{array}{l}\text { HTS of } \\
8 \text { different } \\
\text { rabbits ears. }\end{array}$ & $\begin{array}{l}\text { Rt. ear injected with BTX-A } \\
(0.5 \mathrm{U} \text { per cubic } \mathrm{cm} \text {, } \\
\text { once a month for } \\
3 \text { months }) \text {, Lt. ear as control }\end{array}$ & $\begin{array}{l}\text { Thicknesses of HTS in BTXA group were lower than } \\
\text { in control groups }(\mathrm{P}<0.01) \text {. Collagen fibers were thicker } \\
\text { and arrangement of fibers was disordered in control } \\
\text { group than in BTXA group. }\end{array}$ \\
\hline $\begin{array}{l}\text { Xiao Z et al. } \\
(2010)[42]\end{array}$ & $\begin{array}{l}\text { In-vitro/cell } \\
\text { culture study }\end{array}$ & $\begin{array}{l}\text { HTS tissue } \\
\text { obtained from } \\
8 \text { different } \\
\text { patients }\end{array}$ & $\begin{array}{l}\text { FBs treated with BTX-A } \\
\text { concentration of } \\
1 \mathrm{U} / 10^{6} \text { cells, } \\
2.5 \mathrm{U} / 10^{6} \text { cells, } \\
\text { and control }\end{array}$ & $\begin{array}{l}\text { TGF- } \beta 1 \text { concentration per cell in FBs without BTX-A was } \\
\text { higher than in FBs with BTX-A }(\mathrm{p}<0.01) \text {. Significant } \\
\text { difference noted in TGF- } \beta 1 \text { production per cell between } \\
\text { FBs treated with } 1 \mathrm{U} / 10^{6} \text { cells of BTX-A and FBs treated } \\
\text { with } 2.5 \mathrm{U} / 10^{6} \text { cells of BTX-A }(\mathrm{p}<0.01) \text {. }\end{array}$ \\
\hline $\begin{array}{l}\text { Hao R et al. } \\
(2018)[46]\end{array}$ & $\begin{array}{l}\text { In-vitro } \\
\text { study }\end{array}$ & $\begin{array}{l}\text { Human } \\
\text { Keloid FBs vs. } \\
\text { Normal FBs }\end{array}$ & $\begin{array}{l}\text { FBs treated with different } \\
\text { concentrations of BTX-A } \\
(0.01,0.1,1 \text { and } 10 \mathrm{U} / \mathrm{L})\end{array}$ & $\begin{array}{l}\text { Viability of Keloid FBs decreased with increasing BTXA dose. } \\
\text { BTXA inhibited proliferation, and S phase of Keloid FBs. } \\
\text { MMP-1, -2 RNA and protein showed high expression, but } \\
\text { TGF- } \beta 1 \text { and MMP-9 showed low expression than control. }\end{array}$ \\
\hline $\begin{array}{l}\text { Chen M et al. } \\
\text { (2016) [47] }\end{array}$ & $\begin{array}{l}\text { In-vitro/cell } \\
\text { culture study }\end{array}$ & $\begin{array}{l}\text { Scar } \\
\text { contracture } \\
\text { tissue from } \\
10 \text { patients }\end{array}$ & $\begin{array}{l}\text { BTX-A concentrations } \\
\text { of } 1 \mathrm{U} / 10^{6} \text { cells, } \\
2.5 \mathrm{U} / 10^{6} \text { cells, and control }\end{array}$ & $\begin{array}{l}\text { FBs without BTX-A treatment had higher proliferation } \\
\text { than groups with BTX-A; proliferation of FBs significantly } \\
\text { inhibited by BTX-A }(\mathrm{p}<0.05) \text {. BTX-A also inhibited protein } \\
\text { of } \alpha \text {-SMA and myosin II in FBs treated with BTX-A } \\
\text { compared to FBs without BTXA }(\mathrm{p}<0.05) \text {. }\end{array}$ \\
\hline $\begin{array}{l}\text { Liu DQ et al. } \\
(2017)[72]\end{array}$ & $\begin{array}{l}\text { In-vivo } \\
\text { experiment } \\
\text { (animal } \\
\text { model) }\end{array}$ & $\begin{array}{l}\text { HTS of } \\
18 \text { different } \\
\text { rabbit ears }\end{array}$ & $\begin{array}{l}4 \text { groups: } 12 \text { ears as BTX-A } \\
(0.5,1.0,1.5,2.0 \mathrm{IU}) \\
12 \text { ears as triamcinolone } \\
\text { acetonide (TAC) group, } \\
12 \text { ears phosphate-buffered } \\
\text { saline (PBS), and healthy } \\
\quad \text { skin as control }\end{array}$ & $\begin{array}{l}\text { Mean hypertrophic index of HTS with BTX-A }(2.0 \mathrm{IU}) \\
\text { were lower than that of control }(\mathrm{p}<0.05) \text {. } \\
\text { BTX-A and the TAC group showed significantly less } \\
\text { expression of collagen fibrils compared to PBS. BTXA ( } 2.0 \mathrm{IU}) \\
\text { and TAC significantly reduced FBs compared to control group. }\end{array}$ \\
\hline $\begin{array}{l}\text { Lee BJ et al. } \\
2009[73]\end{array}$ & $\begin{array}{l}\text { Prospective } \\
\text { randomized } \\
\text { experimental } \\
\text { study }\end{array}$ & $\begin{array}{l}\text { Surgical skin } \\
\text { wounding } \\
\text { on the } \\
\text { dorsum of rat }\end{array}$ & $\begin{array}{l}10 \mathrm{U}, 0.5 \mathrm{~mL} \text { BTXA } \\
\text { injected in one wound and } \\
\text { normal saline injected into } \\
\text { adjacent wound as control }\end{array}$ & $\begin{array}{l}\text { Significant differences in wound size at } 3 \text { rd and } 4 \text { th week } \\
\text { between BTXA and control }(\mathrm{p}<0.05) \text {. Less inflammatory } \\
\text { cells in BTXA group than control at } 2 \text { nd week }(\mathrm{p}<0.05) \text {. } \\
\text { BTXA group showed less FBs and fibrosis than control at } \\
4 \text { th week ( }<<0.05) \text {. BTX-A group had strong collagen density } \\
\text { than control at } 8 \text { th week }(\mathrm{p}<0.05) \text {. At } 4 \text { th week, BTX-A group } \\
\text { had lower TGF- } \beta 1 \text { expression than control }(\mathrm{p}<0.05) \text {. }\end{array}$ \\
\hline
\end{tabular}


with BTX-A at monthly intervals for 3 months resulted in remarkable improvement in symptoms of erythema, itching, pliability, and high patient satisfaction [44].

More recently, Hao et al., compared the viability of keloid fibroblast to normal fibroblasts by treating both with increasing dose of BTX-A. At lowered BTX-A concentrations, no significant changes were noted but when the dose was increased to $1 \mathrm{U} / \mathrm{L}$, keloid fibroblast showed fragmentation, increased S phase, increased cell apoptosis and a significant decrease in the number of adherent cells [46]. Other several studies have also reported similar inhibitory effects of BTX-A on keloid or scar-derived fibroblasts. The number of viable fibroblasts was significantly decreased when the fibroblasts derived from both HTS and normal mature scar tissue was treated with BTX-A (0 or 4 units/ml) $(\mathrm{p}<0.001)$, suggesting that BTX-A inhibited the proliferation of fibroblasts [37].

In another study, control fibroblasts from normal tissue showed very high proliferation on the 7 th day, whereas fibroblasts from scar contracture tissue treated with BTX-A $2.5 \mathrm{U} / 10^{6}$ cells showed nucleus pyknosis and significant cellular apoptosis $(\mathrm{p}<0.05)$ [47]. BTX-A not only seems to arrest the proliferation of fibroblasts but also escalates the apoptotic activity, leading to an overall decline in the fibroblast population in the granulation tissue hence controlling the extent of fibrosis.

\subsection{Downregulation of TGF- $\beta 1$ Expression/SMAD Signaling Pathway}

Dysregulation of cytokine TGF- $\beta 1$ seems to be the central driving force in the pathogenesis of HTS and keloids. TGF- $\beta 1$ is a multifunctional growth factor expressed by most cells in wound healing and play a prominent part in signaling cellular proliferation, differentiation, apoptosis and adhesion, stimulation and deposition of ECM, including collagen type I, collagen type III, and fibronectin [42] [48] [49]. Over-expressions of TGF- $\beta 1$ and $-\beta 2$ along with flawed SMAD activity, and decreased expression of TGF- $\beta 3$ increase collagen production and ECM deposition leading to the pathogenesis of abnormal scars [50] [51] [52] [53] [54]. TGF- $\beta 1$ and - $\beta 2$ activates fibroblasts, while TGF- $\beta 3$ is a receptor antagonist and leads to diminished fibroblast activity. In TGF $\beta 1 /$ SMAD signaling pathway, TGF- $\beta 1$ binds to two different trans-membrane receptor serine/threonine kinases and activates the cytoplasmic SMAD proteins. Phosphorylation of receptor-activated SMAD2 and SMAD3 by TGF- $\beta$ receptor type I results in the formation of a complex with Co-SMAD to produce SMAD4 [55]. Through this mechanism TGF- $\beta 1$ activates collagen gene transcription and differentiates fibroblasts into myofibroblasts. Aberration in these processes culminates to abnormal scar pathogenesis.

In different studies, BTX-A has shown to decrease the levels of TGF- $\beta 1$ induced phosphorylation of SMAD2 activity in fibroblasts derived from scar contractures [56] [57]. Since TGF- $\beta 1$ is also secreted by fibroblasts, and BTX-A's ability to directly inhibit the growth and enhance apoptosis of fibroblasts further 
decreases secretion of TGF- $\beta 1$ from these cells and in turn reduces the final fibroblasts turnover. Zhibo et al. found that with BTX-A treatment inhibition of fibroblasts proliferation derived from HTS also coincided with down-regulation of TGF- $\beta 1$ protein expression, highlighting the molecular mechanism of BTX-A in HTS [42]. In in-vitro studies, exogenous addition of neutralizing antibodies to TGF- $\beta 1$ and TGF- $\beta 2$ reduced neovascularization, fibronectin, collagen type III and type I deposition in the early wound healing [54] It also improved the structure of the neo-dermis resembling more closely to that of the normal dermis. Likewise, exogenous administration of TGF- $\beta 3$ peptide had similar effects, whereas wounds treated with TGF- $\beta 1$ or TGF- $\beta 2$ had more extracellular matrix deposition [54]. TGF- $\beta 1$ has been regarded as a dominant cytokine closely linked to the regulation of scar pathogenesis, and the action of BTX-A is effective and significant in the inhibition of HTS and keloid formation through the interference of TGF- $\beta /$ SMAD signaling pathway.

\subsection{Inhibition of Fibroblast to Myofibroblast Differentiation}

In the late proliferative phase, via TGF- $\beta 1$, fibroblasts differentiate to a specialized proto-myofibroblasts, which in response to the cellular changes and mechanical tension forms myofibroblasts. These contractile cells show specific attributes of both fibroblasts and smooth muscle cells. Induced by TGF- $\beta 1$, myofibroblast along with stress fibers containing $\alpha$-smooth muscle actin ( $\alpha$-SMA) enhances increased proliferation, migration, deposition of ECM, and further production of cytokines. It also facilitates wound contraction and thus plays a primary role in the maturation of granulation tissue [58] [59] [60] [61]. Myosin II has a role in the cell deformation, adhesion, and along with actin can regulate the cell contraction process [62] [63] [64]. The contractility of fibroblasts corresponds to the expression of $\alpha$-SMA, and by lessening the expression of $\alpha$-SMA and myosin II, the contraction of scars can be greatly reduced [65] [66]. TGF- $\beta$ is a powerful mediator of myofibroblast differentiation that directly boots myofibroblast maturity by the inducement of $\alpha$-SMA expression, and also function as a stimulant of EMT CTGF, which acts downstream of TGF- $\beta$ to heighten TGF- $\beta$-mediated response [32] [54] [65] [67].

Several animal models and cell culture studies have exhibited that inhibition of TGF- $\beta 1$ signaling at all levels of the pathway effectively prevents myofibroblast formation and development of fibrosis. These studies show that BTX-A inhibits TGF- $\beta 1$, and by blocking this pathway BTX-A successfully inhibits the differentiation of myofibroblasts and their expression of $\alpha$-SMA and myosin II proteins [37] [47]. In a study conducted by Jeong et al., BTX-A treated HTS fibroblasts showed a significant decrease in $\alpha$-SMA transcription, $\alpha$-SMA protein levels, and $\alpha$-SMA staining [37]. Another similar study showed a significant decrease in the expression of $\alpha$-SMA mRNA levels in fibroblasts derived from HTS when treated with BTX-A [47]. Since $\alpha$-SMA is a marker for myofibroblast, the decreased level of $\alpha$-SMA in all these studies clearly show the inhibitory effect of BTX-A on TGF- $\beta 1$ signaling and subsequent prevention of myofibroblast diffe- 
rentiation by downregulating TGF- $\beta 1$ expression. These can partly explain the molecular mechanism and effect of BTX-A on fibroblasts thus curtailing abnormal scarring.

\subsection{BTX-A on the Expression of Collagen, MMP-1, MMP-2, and MMP-9}

Collagen is a long fibrous protein displaying outstanding endurance and is one of the main components of ECM. Fibroblasts in the proliferative phase synthesize collagen and together with elastin and soft keratin, they provide tensile strength and elasticity to tissues. With regard to normal fibroblasts, there is a 3 -fold increase of collagen in HTS and a 20 -fold increase in keloids, leading to a larger and abnormal scar [68]. Histologically, HTS has more of collagen type III in a wavy, regular pattern arranged parallel to the skin surface, whereas keloids have a haphazard pattern, or nodular, whorls of collagen type I and type III [69].

TGF- $\beta 1$ has demonstrated to up-regulate the expression of different types of collagen in cultured fibroblasts, and excessive collagen is a key feature of HTS and keloid. In one recent study, keloid fibroblasts treated with BTX-A (0.5 unit $/ 10^{5}$ cells) significantly decreased collagen type III mRNA expression $(\mathrm{p}<$ 0.05) compared to no treatment control [70]. Collagen type III expression also decreased significantly in BTX-A of 0.5 unit $/ 10^{5}$ cells with TGF- $\beta 1$ compared to TGF- $\beta 1$ alone [70]. In another cell culture study, collagen type $\mathrm{I}_{\alpha 1}$ was significantly decreased $(\mathrm{p}<0.05)$ by BTX-A but collagen type III expression was not affected in the same study [57]. In other animal model studies, characteristics of collagen in HTS were compared with controls to assess the effects of BTX-A on hyper-proliferative scars [39] [71] [72] [73]. Scar thickness and deposition of collagen was examined histologically. HTS tissue administered with BTX-A showed a decrease in the number of collagen fibrils with more organized fibers, absent of granulomatous or inflammatory infiltrates. The control had thicker collagen fibers with a haphazard arrangement. The BTX-A treated group also showed diminished expression of TGF- $\beta 1$ in one of the animal model studies [73].

MMPs are matrix metalloproteinases that are regulated by TGF- $\beta 1$ and have an important role in the regulation of synthesis and breakdown of ECM. MMP-1 (collagenase) and MMP-2 (gelatinase-A) degrade ECM during tissue remodeling and reduction in the synthesis of these molecules may explain the lack of scar regression seen in abnormal scarring [74]. In one study, when keloid fibroblasts were treated with BTX-A, it resulted in a substantial increase in the expressions of MMP-1 and MMP-2 genes in comparison to normal fibroblasts, but the expressions of TGF- $\beta 1$ gene and MMP-9 declined with increasing toxin dose [46]. Other studies showed a significant increase in MMP-1 mRNA expression and MMP-2 activity in keloid fibroblasts compared with the control group $(\mathrm{p}<0.05)$ after treatment with BTX-A even without the addition of exogenous TGF- $\beta$ [70]. In another experimental study, fibroblasts treated with BTX-A with or without 
the combination of TGF- $\beta 1$ significantly increased MMP-2 and matrix MMP-9 expression when compared to control group ( $\mathrm{p}<0.05$ ), but MMP-2 decreased significantly after treatment with only TGF- $\beta 1$ [57]. These studies suggest that BTX-A inhibits TGF- $\beta 1$ and as a result increases the expression of MMP- 1 and MMP-2 which then prevents excess collagen and ECM deposition, resulting in less fibrosis. BTX-A thus downregulates collagen expression and upregulates MMPs to reduce overtly synthesized ECM.

\subsection{BTX-A Inhibits Connective Tissue Growth Factor (CTGF) Expression}

Connective tissue growth factor (CTGF) is a pro-fibrotic and a downstream regulator of some of the responses of TGF- $\beta 1$ functions. Induction of this complex molecule by TGF- $\beta 1$ produce prolonged signaling of collagen mRNA expression, resulting in excessive collagen deposition, cellular adhesion, and growth leading to a state of sustained fibrosis [75] [76] [77] [78]. Therefore, blocking CTGF can prevent the synergistic effect of CTGF and TGF- $\beta 1$ on hyper-proliferative scars. CTGF is excessively expressed in dermal fibrotic lesions like keloids, HTS, scleroderma, fibro-sarcomas, and as well as in lung, gingival, and liver fibrosis [79]-[84]. The elevated level of CTGF expression observed in fibrotic lesions is one of the best molecular markers of the fibrotic phenotype.

The effects of BTX-A on CTGF in hypertrophic scar still are largely unknown. However, a study exhibited that BTX-A adequately suppressed the growth of fibroblasts derived from HTS in 8 different patients, which in turn bring about a significant decrease in CTGF expression [40]. Compared to fibroblasts without BTX-A treatment, HTS derived fibroblasts when treated with BTX-A at 1.0 $\mathrm{U} / 10^{6}$ cells reduced CTGF expression by $49.2 \% \pm 12.5 \%(\mathrm{p}<0.01)$, and with BTX-A at $2.5 \mathrm{U} / 10^{6}$ cells reduced CTGF expression by $56.9 \%$ ( $\mathrm{p}<0.01$ ) [40]. These results displayed that BTX-A had significant effects on the down-regulation of CTGF expression. So, the capacity of BTX-A to reduce CTGF expression and inhibit fibroblast proliferation may be associated with clinical improvement in the hypertrophic scar.

\subsection{Relieves Wound Tension}

Skin-tension is a known cause that acts on the wound borders during the healing process and prolongs the inflammatory reactions that aggravate fibrosis. The mechanical tension of skin closure is converted chemically into complex signaling that releases cytokines, particularly TGF- $\beta 1$, that directly influence the quality of a scar [85] [86]. The mechanical stress detected by the mechanoreceptors in cells stimulates myofibroblast contraction that activates latent TGF- $\beta 1$ in the ECM [87] [88]. Thus, this mechano-chemical stimulation accelerates the induction of cell proliferation, collagen synthesis and upregulation of expressions of TGF- $\beta 1$, integrin- $\beta 1$, and cytoskeleton p130Cas [87] [89] [90]. It is known that wound edges perpendicular to the relaxed skin tension lines (RSTL) pull the wound muscles and tissues with an opposing force that impedes the normal 
wound healing process, and leads to sustained inflammation and fibrosis leading to the formation of HTS and keloids.

BTX-A, when injected locally, causes temporary paralysis of the muscles and tissues in the wound edges and reduces the dynamic muscle tension to enhance the healing process by blocking the mechanotransduction [88] [90] [91] [92]. In the year 2000, Gassner et al., used BTX-A on primates to show the effect it had on wound tension [93]. Gassner et al., in another study showed that BTX-A immobilized wound edges when injected locally in facial wounds resulting in a better cosmetic outcome compared to the controls [94]. Gassner conducted several studies and showed promising results of the effect of chemo-immobilization on wounds by injecting BTX-A locally [94] [95] [96]. Other studies have also effectively concluded that BTX-A injection can relax the wound edges in the anatomic locations prone to tensile stress by temporary paralysis of the muscles resulting in a far better outcome than in the controls [97] [98].

\section{Conclusion}

In this manuscript, the authors have studied responses of botulinum toxin type-A on wound healing and preventing pathological scars like HTS and keloids, and comprehended the overall effect BTX-A has on wound healing. The mechanisms of BTX-A on the prevention of HTS and keloids are still not understood very well but the staggering amount of results of in vivo and in vitro experiments has indeed identified a number of effects of BTX-A on non-neuronal cells in the skin. This multifunctional toxin seems to have a direct action on dermal fibroblasts, TGF- $\beta 1$ expression and wound tension, and if effectively applied in the very early stages of wound healing can regress abnormal scarring and prevent HTS and keloids. However, there is much to be investigated regarding the mechanism of actions of BTX-A on wound healing and doors are just opening for further studies.

\section{Conflicts of Interest}

None declared.

\section{References}

[1] Ziade, M., et al. (2013) Use of Botulinum Toxin Type A to Improve Treatment of Facial Wounds: A Prospective Randomised Study. Journal of Plastic, Reconstructive \& Aesthetic Surgery, 66, 209-214. https://doi.org/10.1016/j.bjps.2012.09.012

[2] Zhang, D.Z., et al. (2016) Botulinum Toxin Type A and the Prevention of Hypertrophic Scars on the Maxillofacial Area and Neck: A Meta-Analysis of Randomized Controlled Trials. PLoS ONE, 11, e0151627. https://doi.org/10.1371/journal.pone.0151627

[3] Leventhal, D., Furr, M. and Reiter, D. (2006) Treatment of Keloids and Hypertrophic Scars: A Meta-Analysis and Review of the Literature. Archives of Facial Plastic Surgery, 8, 362-368. https://doi.org/10.1001/archfaci.8.6.362

[4] Kerner, J.A.C. (1820) Neue Beobachtungen über die in Württemberg so häufig vor- 
fallenden tödlichen Vergiftungen durch den Genuss geräucherter Würste.

[5] Kerner, J.A.C. (1822) Das Fettgift, oder die Fettsal0308ure und ihre Wirkungen auf den thierischen Organismus, etc.

[6] Hagenah, R., Benecke, R. and Wiegand, H. (1977) Effects of Type a Botulinum Toxin on the Cholinergic Transmission at Spinal Renshaw Cells and on the Inhibitory Action at Ia Inhibitory Interneurones. Naunyn-Schmiedeberg's Archives of Pharmacology, 299, 267-272. https://doi.org/10.1007/BF00500319

[7] Nix, W.A. (2007) Botulinum Toxin in Chronic Myofascial Pain. Schmerz, 21, 467-468. https://doi.org/10.1007/s00482-007-0567-y

[8] Ashkenazi, A. and Silberstein, S. (2008) Botulinum Toxin Type A for the Treatment of Headache: Why We Say Yes. Archives of Neurology, 65, 146-149. https://doi.org/10.1001/archneurol.2007.20

[9] Wheeler, T. (2012) Sweat and Tears: Treating the Patient with Primary Hyperhidrosis. British Journal of Nursing, 21, 408, 410-412.

https://doi.org/10.12968/bjon.2012.21.7.408

[10] Santos-Silva, A., da Silva, C.M. and Cruz, F. (2013) Botulinum Toxin Treatment for Bladder Dysfunction. International Journal of Urology, 20, 956-962. https://doi.org/10.1111/iju.12188

[11] Beer, K. and Waibel, J. (2007) Botulinum Toxin Type A Enhances the Outcome of Fractional Resurfacing of the Cheek. Journal of Drugs in Dermatology, 6, 1151-1152.

[12] Lee, H., Saladi, R.N. and Fox, J.L. (2008) Cohort Study on Patient Response to Botulinum Toxin Cosmetic Therapy. Journal of Cosmetic Dermatology, 7, 39-42. https://doi.org/10.1111/j.1473-2165.2008.00359.x

[13] Egan, M. (2014) Botox Maker Bought for \$66 Billion in Biggest Deal of 2014. http://money.cnn.com/2014/11/17/investing/allergan-actavis-merger-boom

[14] Allergan (2015) Actavis plc Is Now Allergan plc.

[15] Felber, E.S. (2006) Botulinum Toxin in Primary Care Medicine. The Journal of the American Osteopathic Association, 106, 609-614.

[16] Li, B., et al. (2010) Small Molecule Inhibitors as Countermeasures for Botulinum Neurotoxin Intoxication. Molecules, 16, 202-220. https://doi.org/10.3390/molecules16010202

[17] Montecucco, C. and Molgo, J. (2005) Botulinal Neurotoxins: Revival of an Old Killer. Current Opinion in Pharmacology, 5, 274-279. https://doi.org/10.1016/j.coph.2004.12.006

[18] Pirazzini, M., et al. (2017) Botulinum Neurotoxins: Biology, Pharmacology, and Toxicology. Pharmacological Reviews, 69, 200-235. https://doi.org/10.1124/pr.116.012658

[19] Lacy, D.B., et al. (1998) Crystal Structure of Botulinum Neurotoxin Type A and Implications for Toxicity. Nature Structural Biology, 5, 898-902. https://doi.org/10.1038/2338

[20] de Paiva, A., et al. (1999) Functional Repair of Motor Endplates after Botulinum Neurotoxin Type A Poisoning: Biphasic Switch of Synaptic Activity between Nerve Sprouts and Their Parent Terminals. Proceedings of the National Academy of Sciences of the United States of America, 96, 3200-3205. https://doi.org/10.1073/pnas.96.6.3200

[21] Davies, J.R., et al. (2018) High Resolution Crystal Structures of Clostridium botulinum Neurotoxin A3 and A4 Binding Domains. Journal of Structural Biology, 202, 113-117. https://doi.org/10.1016/j.jsb.2017.12.010 
[22] Rossetto, O., Pirazzini, M. and Montecucco, C. (2014) Botulinum Neurotoxins: Genetic, Structural and Mechanistic Insights. Nature Reviews Microbiology, 12, 535-349. https://doi.org/10.1038/nrmicro3295

[23] Montecucco, C. (1986) How Do Tetanus and Botulinum Toxins Bind to Neuronal Membranes? Trends in Biochemical Sciences, 11, 314-317. https://doi.org/10.1016/0968-0004(86)90282-3

[24] Brunger, A.T. and Rummel, A. (2009) Receptor and Substrate Interactions of Clostridial Neurotoxins. Toxicon, 54, 550-560. https://doi.org/10.1016/j.toxicon.2008.12.027

[25] Zhang, Y., et al. (2012) Simultaneous and Sensitive Detection of Six Serotypes of Botulinum Neurotoxin Using Enzyme-Linked Immunosorbent Assay-Based Protein Antibody Microarrays. Analytical Biochemistry, 430, 185-192.

https://doi.org/10.1016/j.ab.2012.08.021

[26] Pellett, S., et al. (2018) The Light Chain Defines the Duration of Action of Botulinum Toxin Serotype A Subtypes. mBio, 9, pii: e00089-18. https://doi.org/10.1128/mBio.00089-18

[27] Pirazzini, M., et al. (2015) The Thioredoxin Reductase-Thioredoxin Redox System Cleaves the Interchain Disulphide Bond of Botulinum Neurotoxins on the Cytosolic Surface of Synaptic Vesicles. Toxicon, 107, 32-36. https://doi.org/10.1016/j.toxicon.2015.06.019

[28] Arnon, S.S., et al. (2001) Botulinum Toxin as a Biological Weapon: Medical and Public Health Management. JAMA, 285, 1059-1070. https://doi.org/10.1001/jama.285.8.1059

[29] Flanagan, M. (2013) Wound Healing and Skin Integrity: Principles and Practice. John Wiley and Sons Ltd., Hoboken.

[30] Gauglitz, G.G., et al. (2011) Hypertrophic Scarring and Keloids: Pathomechanisms and Current and Emerging Treatment Strategies. Molecular Medicine, 17, 113-125. https://doi.org/10.2119/molmed.2009.00153

[31] Roberts, A.B. and Sporn, M.B. (1993) Physiological Actions and Clinical Applications of Transforming Growth Factor-Beta (TGF-Beta). Growth Factors, 8, 1-9. https://doi.org/10.3109/08977199309029129

[32] Biernacka, A., Dobaczewski, M. and Frangogiannis, N.G. (2011) TGF-Beta Signaling in Fibrosis. Growth Factors, 29, 196-202. https://doi.org/10.3109/08977194.2011.595714

[33] Mayrand, D., et al. (2012) Angiogenic Properties of Myofibroblasts Isolated from Normal Human Skin Wounds. Angiogenesis, 15, 199-212. https://doi.org/10.1007/s10456-012-9253-5

[34] Pastar, I., et al. (2014) Epithelialization in Wound Healing: A Comprehensive Review. Advances in Wound Care (New Rochelle), 3, 445-464. https://doi.org/10.1089/wound.2013.0473

[35] Su, W.H., et al. (2010) Nonsteroidal Anti-Inflammatory Drugs for Wounds: Pain Relief or Excessive Scar Formation? Mediators of Inflammation, 2010, Article ID: 413238. https://doi.org/10.1155/2010/413238

[36] Butzelaar, L., et al. (2016) Currently Known Risk Factors for Hypertrophic Skin Scarring: A Review. Journal of Plastic, Reconstructive \& Aesthetic Surgery, 69, 163-169. https://doi.org/10.1016/j.bjps.2015.11.015

[37] Jeong, H.S., et al. (2015) Effect of Botulinum Toxin Type A on Differentiation of Fibroblasts Derived from Scar Tissue. Plastic and Reconstructive Surgery, 136, 
171e-178e. https://doi.org/10.1097/PRS.0000000000001438

[38] Oh, S.H., et al. (2012) The Potential Effect of Botulinum Toxin Type A on Human Dermal Fibroblasts: An in Vitro Study. Dermatologic Surgery, 38, 1689-1694. https://doi.org/10.1111/j.1524-4725.2012.02504.x

[39] Xiao, Z. and Qu, G. (2012) Effects of Botulinum Toxin Type a on Collagen Deposition in Hypertrophic Scars. Molecules, 17, 2169-2177. https://doi.org/10.3390/molecules17022169

[40] Xiao, Z., et al. (2011) Botulinum Toxin Type a Inhibits Connective Tissue Growth Factor Expression in Fibroblasts Derived from Hypertrophic Scar. Aesthetic Plastic Surgery, 35, 802-807. https://doi.org/10.1007/s00266-011-9690-3

[41] Wang, L., Tai, N.Z. and Fan, Z.H. (2009) Effect of Botulinum Toxin Type A Injection on Hypertrophic Scar in Rabbit Ear Model. Chinese Journal of Plastic Surgery, 25, 284-287.

[42] Xiao, Z., et al. (2010) Effect of Botulinum Toxin Type A on Transforming Growth Factor Beta1 in Fibroblasts Derived from Hypertrophic Scar: A Preliminary Report. Aesthetic Plastic Surgery, 34, 424-427. https://doi.org/10.1007/s00266-009-9423-Z

[43] Zhibo, X. and Miaobo, Z. (2009) Intralesional Botulinum Toxin Type A Injection as a New Treatment Measure for Keloids. Plastic and Reconstructive Surgery, 124, 275e-277e. https://doi.org/10.1097/PRS.0b013e3181b98ee7

[44] Xiao, Z., Zhang, F. and Cui, Z. (2009) Treatment of Hypertrophic Scars with Intralesional Botulinum Toxin Type A Injections: A Preliminary Report. Aesthetic Plastic Surgery, 33, 409-412. https://doi.org/10.1007/s00266-009-9334-Z

[45] Zhibo, X. and Miaobo, Z. (2008) Botulinum Toxin Type A Affects Cell Cycle Distribution of Fibroblasts Derived from Hypertrophic Scar. Journal of Plastic, Reconstructive \& Aesthetic Surgery, 61, 1128-1129. https://doi.org/10.1016/j.bjps.2008.05.003

[46] Hao, R., et al. (2018) Efficacy and Possible Mechanisms of Botulinum Toxin Type A on Hypertrophic Scarring. Journal of Cosmetic Dermatology, 17, 340-346. https://doi.org/10.1111/jocd.12534

[47] Chen, M., et al. (2016) Botulinum Toxin Type A Inhibits alpha-Smooth Muscle Actin and Myosin II Expression in Fibroblasts Derived From Scar Contracture. Annals of Plastic Surgery, 77, e46-e49. https://doi.org/10.1097/SAP.0000000000000268

[48] Raghow, R., et al. (1987) Transforming Growth Factor-Beta Increases Steady State Levels of Type I Procollagen and Fibronectin Messenger RNAs Posttranscriptionally in Cultured Human Dermal Fibroblasts. Journal of Clinical Investigation, 79, 1285-1288. https://doi.org/10.1172/JCI112950

[49] Chen, M.A. and Davidson, T.M. (2005) Scar Management: Prevention and Treatment Strategies. Current Opinion in Otolaryngology \& Head and Neck Surgery, 13, 242-247. https://doi.org/10.1097/01.moo.0000170525.74264.f8

[50] Fujiwara, M., Muragaki, Y. and Ooshima, A. (2005) Keloid-Derived Fibroblasts Show Increased Secretion of Factors Involved in Collagen Turnover and Depend on Matrix Metalloproteinase for Migration. British Journal of Dermatology, 153, 295-300. https://doi.org/10.1111/j.1365-2133.2005.06698.x

[51] Tanriverdi-Akhisaroglu, S., Menderes, A. and Oktay, G. (2009) Matrix Metalloproteinase-2 and -9 Activities in Human Keloids, Hypertrophic and Atrophic Scars: A Pilot Study. Cell Biochemistry and Function, 27, 81-87. https://doi.org/10.1002/cbf.1537

[52] Babalola, O., et al. (2013) The Role of microRNAs in Skin Fibrosis. Archives of 
Dermatological Research, 305, 763-776. https://doi.org/10.1007/s00403-013-1410-1

[53] Wolfram, D., et al. (2009) Hypertrophic Scars and Keloids-A Review of Their Pathophysiology, Risk Factors, and Therapeutic Management. Dermatologic Surgery, 35, 171-181. https://doi.org/10.1111/j.1524-4725.2008.34406.x

[54] Shah, M., Foreman, D.M. and Ferguson, M.W. (1995) Neutralisation of TGF-beta 1 and TGF-beta 2 or Exogenous Addition of TGF-beta 3 to Cutaneous Rat Wounds Reduces Scarring. Journal of Cell Science, 108, 985-1002.

[55] Shi, Y. and Massague, J. (2003) Mechanisms of TGF-beta Signaling from Cell Membrane to the Nucleus. Cell, 113, 685-700. https://doi.org/10.1016/S0092-8674(03)00432-X

[56] Lee, S.D., et al. (2016) The Effect of Botulinum Neurotoxin Type A on Capsule Formation around Silicone Implants: The in Vivo and in Vitro Study. International Wound Journal, 13, 65-71. https://doi.org/10.1111/iwj.12228

[57] Kim, S., et al. (2016) Effect of Botulinum Toxin Type A on TGF-beta/Smad Pathway Signaling: Implications for Silicone-Induced Capsule Formation. Plastic and Reconstructive Surgery, 138, 821e-829e. https://doi.org/10.1097/PRS.0000000000002625

[58] Gabbiani, G., Ryan, G.B. and Majne, G. (1971) Presence of Modified Fibroblasts in Granulation Tissue and Their Possible Role in Wound Contraction. Experientia, 27, 549-550. https://doi.org/10.1007/BF02147594

[59] Gabbiani, G. (2003) The Myofibroblast in Wound Healing and Fibrocontractive Diseases. The Journal of Pathology, 200, 500-503. https://doi.org/10.1002/path.1427

[60] Hinz, B., et al. (2007) The Myofibroblast: One Function, Multiple Origins. The American Journal of Pathology, 170, 1807-1816.

https://doi.org/10.2353/ajpath.2007.070112

[61] Darby, I.A. and Hewitson, T.D. (2007) Fibroblast Differentiation in Wound Healing and Fibrosis. International Review of Cytology, 257, 143-179. https://doi.org/10.1016/S0074-7696(07)57004-X

[62] Tanaka, J., et al. (1993) Morphological and Biochemical Analyses of Contractile Proteins (Actin, Myosin, Caldesmon and Tropomyosin) in Normal and Transformed Cells. Journal of Cell Science, 104, 595-606.

[63] Bond, J.E., et al. (2011) Temporal Spatial Expression and Function of Non-Muscle Myosin II Isoforms IIA and IIB in Scar Remodeling. Laboratory Investigation, 91, 499-508. https://doi.org/10.1038/labinvest.2010.181

[64] Vicente-Manzanares, M., et al. (2009) Non-Muscle Myosin II Takes Centre Stage in Cell Adhesion and Migration. Nature Reviews Molecular Cell Biology, 10, 778-790. https://doi.org/10.1038/nrm2786

[65] Tomasek, J.J., et al. (2002) Myofibroblasts and Mechano-Regulation of Connective Tissue Remodelling. Nature Reviews Molecular Cell Biology, 3, 349-363. https://doi.org/10.1038/nrm809

[66] Zaleskas, J.M., et al. (2001) Growth Factor Regulation of Smooth Muscle Actin Expression and Contraction of Human Articular Chondrocytes and Meniscal Cells in a Collagen-GAG Matrix. Experimental Cell Research, 270, 21-31. https://doi.org/10.1006/excr.2001.5325

[67] Arno, A.I., et al. (2014) New Molecular Medicine-Based Scar Management Strategies. Burns, 40, 539-551. https://doi.org/10.1016/j.burns.2013.11.010

[68] Berman, B., Maderal, A. and Raphael, B. (2017) Keloids and Hypertrophic Scars: Pathophysiology, Classification, and Treatment. Dermatologic Surgery, 43, S3-S18. https://doi.org/10.1097/DSS.0000000000000819 
[69] Jumper, N., Paus, R. and Bayat, A. (2015) Functional Histopathology of Keloid Disease. Histology and Histopathology, 30, 1033-1057.

[70] Roh, T.S., et al. (2013) The Effects of Botulinum Toxin A on Collagen Synthesis, Expression of MMP (Matrix Metalloproteinases)-1,2,9 and TIMP (Tissue Inhibitors of Metalloproteinase)-1 in the Keloid Fibroblasts. Archives of Aesthetic Plastic Surgery, 19, 114-119. https://doi.org/10.14730/aaps.2013.19.2.114

[71] Fanous, A., et al. (2019) Treatment of Keloid Scars with Botulinum Toxin Type A versus Triamcinolone in an Athymic Nude Mouse Model. Plastic and Reconstructive Surgery, 143, 760-767. https://doi.org/10.1097/PRS.0000000000005323

[72] Liu, D.Q., Li, X.J. and Weng, X.J. (2017) Effect of BTXA on Inhibiting Hypertrophic Scar Formation in a Rabbit Ear Model. Aesthetic Plastic Surgery, 41, 721-728. https://doi.org/10.1007/s00266-017-0803-5

[73] Lee, B.J., et al. (2009) Effect of Botulinum Toxin Type a on a Rat Surgical Wound Model. Clinical and Experimental Otorhinolaryngology, 2, 20-27. https://doi.org/10.3342/ceo.2009.2.1.20

[74] Niessen, F.B., et al. (1999) On the Nature of Hypertrophic Scars and Keloids: A Review. Plastic and Reconstructive Surgery, 104, 1435-1458.

https://doi.org/10.1097/00006534-199910000-00031

[75] Grotendorst, G.R. (1997) Connective Tissue Growth Factor: A Mediator of TGF- $\beta$ Action on Fibroblasts. Cytokine \& Growth Factor Reviews, 8, 171-179. https://doi.org/10.1016/S1359-6101(97)00010-5

[76] Duncan, M.R., et al. (1999) Connective Tissue Growth Factor Mediates Transforming Growth Factor Beta-Induced Collagen Synthesis: Down-Regulation by cAMP. The FASEB Journal, 13, 1774-1786. https://doi.org/10.1096/fasebj.13.13.1774

[77] Weston, B.S., Wahab, N.A. and Mason, R.M. (2003) CTGF Mediates TGF-Beta-Induced Fibronectin Matrix Deposition by Upregulating Active Alpha5beta1 Integrin in $\mathrm{Hu}-$ man Mesangial Cells. Journal of the American Society of Nephrology, 14, 601-610. https://doi.org/10.1097/01.ASN.0000051600.53134.B9

[78] Abreu, J.G., et al. (2002) Connective-Tissue Growth Factor (CTGF) Modulates Cell Signalling by BMP and TGF-Beta. Nature Cell Biology, 4, 599-604. https://doi.org/10.1038/ncb826

[79] Igarashi, A., et al. (1996) Connective Tissue Growth Factor Gene Expression in Tissue Sections from Localized Scleroderma, Keloid, and Other Fibrotic Skin Disorders. Journal of Investigative Dermatology, 106, 729-733. https://doi.org/10.1111/1523-1747.ep12345771

[80] Lasky, J.A., et al. (1998) Connective Tissue Growth Factor mRNA Expression Is Upregulated in Bleomycin-Induced Lung Fibrosis. American Journal of Physiology, 275, L365-L371. https://doi.org/10.1152/ajplung.1998.275.2.L365

[81] Paradis, V., et al. (1999) Expression of Connective Tissue Growth Factor in Experimental Rat and Human Liver Fibrosis. Hepatology, 30, 968-976.

https://doi.org/10.1002/hep.510300425

[82] Chen, S.J., et al. (1999) Stimulation of Type I Collagen Transcription in Human Skin Fibroblasts by TGF-Beta: Involvement of Smad 3. Journal of Investigative Dermatology, 112, 49-57. https://doi.org/10.1046/j.1523-1747.1999.00477.x

[83] Uzel, M.I., et al. (2001) Connective Tissue Growth Factor in Drug-Induced Gingival Overgrowth. Journal of Periodontology, 72, 921-931.

https://doi.org/10.1902/jop.2001.72.7.921

[84] Leask, A., Holmes, A. and Abraham, D.J. (2002) Connective Tissue Growth Factor: 
A New and Important Player in the Pathogenesis of Fibrosis. Current Rheumatology Reports, 4, 136-142. https://doi.org/10.1007/s11926-002-0009-x

[85] Mustoe, T.A., et al. (2002) International Clinical Recommendations on Scar Management. Plastic and Reconstructive Surgery, 110, 560-571.

https://doi.org/10.1097/00006534-200208000-00031

[86] Derderian, C.A., et al. (2005) Mechanical Strain Alters Gene Expression in an in Vitro Model of Hypertrophic Scarring. Annals of Plastic Surgery, 55, 69-75. https://doi.org/10.1097/01.sap.0000168160.86221.e9

[87] Ogawa, R. (2008) Keloid and Hypertrophic Scarring May Result from a Mechanoreceptor or Mechanosensitive Nociceptor Disorder. Medical Hypotheses, 71, 493-500. https://doi.org/10.1016/j.mehy.2008.05.020

[88] Wipff, P.J., et al. (2007) Myofibroblast Contraction Activates Latent TGF-beta1 from the Extracellular Matrix. Journal of Cell Biology, 179, 1311-1323. https://doi.org/10.1083/jcb.200704042

[89] Kuang, R., et al. (2015) Influence of Mechanical Stimulation on Human Dermal Fibroblasts Derived from Different Body Sites. International Journal of Clinical and Experimental Medicine, 8, 7641-7647.

[90] Shu, M.G., Han, Y., Yang, L., Zhang, L.X., Xia, W.S., Liu, D. and Guo, S.Z. (2008) The Effect of Mechanical Stress on the Expression of Growth Factor in Human Skin Fibroblasts. Chinese Journal of Aesthetic Medicine, 17, 689-691.

[91] Carruthers, A. and Carruthers, J. (2001) Botulinum Toxin Type A: History and Current Cosmetic Use in the Upper Face. Seminars in Cutaneous Medicine and Surgery, 20, 71-84. https://doi.org/10.1053/sder.2001.25138

[92] Silberstein, E., et al. (2018) Effect of Botulinum Toxin A on Muscle Healing and Its Implications in Aesthetic and Reconstructive Surgery. Aesthetic Surgery Journal, 38, 557-561. https://doi.org/10.1093/asj/sjx207

[93] Gassner, H.G., Sherris, D.A. and Otley, C.C. (2000) Treatment of Facial Wounds with Botulinum Toxin A Improves Cosmetic Outcome in Primates. Plastic and Reconstructive Surgery, 105, 1948-1953. https://doi.org/10.1097/00006534-200005000-00005

[94] Gassner, H.G. and Sherris, D.A. (2003) Chemoimmobilization: Improving Predictability in the Treatment of Facial Scars. Plastic and Reconstructive Surgery, 112, 1464-1466. https://doi.org/10.1097/01.PRS.0000081073.94689.DB

[95] Gassner, H.G., et al. (2006) Botulinum Toxin to Improve Facial Wound Healing: A Prospective, Blinded, Placebo-Controlled Study. Mayo Clinic Proceedings, 81, 1023-1028. https://doi.org/10.4065/81.8.1023

[96] Gassner, H.G., Sherris, D.A. and Friedman, O. (2009) Botulinum Toxin-Induced Immobilization of Lower Facial Wounds. Archives of Facial Plastic Surgery, 11, 140-142. https://doi.org/10.1001/archfacial.2009.3

[97] Tollefson, T.T., et al. (2006) Botulinum Toxin to Improve Results in Cleft Lip Repair. Archives of Facial Plastic Surgery, 8, 221-222. https://doi.org/10.1001/archfaci.8.3.221

[98] Choi, J.C., Lucarelli, M.J. and Shore, J.W. (1997) Use of Botulinum A Toxin in Patients at Risk of Wound Complications Following Eyelid Reconstruction. Ophthalmic Plastic and Reconstructive Surgery, 13, 259-264.

https://doi.org/10.1097/00002341-199712000-00006 


\section{Abbreviations}

BTX-A: Botulinum Toxin Type-A; NMJ: Neuromuscular Junction; ECM: Extracellular Matrix; HTS: Hypertrophic Scar; TGF $\beta$-1: Transforming Growth Factor $\beta$-1; MMP: Matrix Metalloproteinase; CTGF: Connective Tissue Growth Factor; EMT: Epithelial-Mesenchymal Transition 